\title{
The Learning Climate of Chartered Quantity Surveying Practices
}

David Lowe, (The University of Manchester, UK)

Martin Skitmore, (Queensland University of Technology, Australia)

\begin{abstract}
This paper reports on a fully structured interview survey investigating the relationship between the learning climate of chartered quantity surveying practices and individual learning styles, approaches to learning, ability, measures of length of service and the size of the quantity surveying organisation. The results indicate that the learning environment is generally supportive in terms of human support, but less supportive in terms of staff development systems; as individuals rise in the hierarchy of an organisation, their perception of its ability to provide an appropriate learning environment increases. Likewise, perceptions of human support and working practices within organisations increase significantly with length of time in the profession; larger organisations have more advanced staff development systems but provide less human support; and the learning environment both overall and in terms of working practices correlates positively with learning styles and approaches to learning.
\end{abstract}

Keywords: Learning organization, Experiential learning, Learning styles, Practitioners, Quantity surveying

\section{Introduction}

Professional practitioners, it is held, continually learn on the job, as their work necessitates involvement in a series of projects, problems or cases which are new to them. Learning from experience, therefore, is extremely important in professional development, and requires an ability to conceptualise and an ability to evaluate. Further, it is important for professionals to sustain a critical and evaluative attitude towards practice, so that they seek to improve it and do not lapse into complacency.

Learning also occurs within a social context and is a social phenomenon as well as an individualistic one (Jarvis, 1987), while different learning environments require different skills of learners (Kolb, 1976) and impose "... different strategies of learning; individuals try to adapt to the demands and opportunities presented by the content of what is to be learned and its institutional setting" (Ramsden, 1988). Several researchers have hypothesised that learning styles affect behaviour in the workplace (Gish, 1980; Manring, 1979; Miller, 1978; Sims, 1983). However, there is a lack of evidence concerning exactly what is learned and how professionals learn from experience (Eraut, 1994).

Practitioners in the context of this paper are Chartered Quantity Surveyors. Quantity surveyors are appointed by construction clients to provide cost expertise, advise on the choice of materials, construction and procurement processes, deal with planning, building regulations and architects, and to provide contract expertise (Thompson, 2004). Learning through experience is well known in the profession and several recommendations have been made to facilitate this, especially in the form of feedback mechanisms (e.g., Flanagan and Norman 1983; Morrison 1984; Ogunlana 1989). Previous empirical research also confirms that quantity surveyors rely to a significant extent on their work experience in activities such as cost estimating (Lowe and Skitmore, 1994) and has investigated the extent to which individual surveyors' learning styles affect the way such experiences are utilised (Lowe and Skitmore, 2001). 
This paper reports on the results of a study investigating the extent to which learning by experience is applicable in quantity surveying organisations and the effect on their employees who provide early stage building price forecasts, in particular:

- the practitioner's perceptions of the learning climate of their organisation

- relationships between the learning climate and measures of: length of experience, ability and the size of the organisation/practice, and

- relationships between the learning climate and individual learning styles of and approaches to learning.

\section{Learning in the Work Place}

Learning in the workplace takes place in many situations: formal, informal or incidental. Informal learning within the workplace is predominantly experiential and non-institutional, including self-directed learning, networking, coaching, mentoring, performance planning and trial-and-error (Marsick and Watkins, 1990). Incidental learning, however, is unintentional, a by-product of another activity, examples include: learning from mistakes, assumptions, beliefs, attributions and internalised meaning constructions about actions of others. Much incidental learning is unintended, where learning opportunities are derived from everyday experiences or perceptions (Rogers, 1986). For most employed individuals, 95\% of learning is achieved 'on the job' (Lewis and Margerison, 1979), with learning occurring naturally in the work environment rather than through structured learning activities (Binsted, 1980; Mumford, 1987).

The most significant factors that have been found to influence learning within organisations comprise: relations with other people, degree of autonomy, and policies and commitment towards training and learning; with the factors hindering learning being: other people's characteristics, organisational structures, the environment and job characteristics (Vandenput, 1973). Opportunities for work-based learning are, therefore, crucially dependent on the way in which work is organised and allocated (Eraut, $1994 \mathrm{p} \mathrm{168).}$

The employees' capacity to recognise opportunities, know what they are learning and how they are learning, however, varies considerably (Mumford, 1990), with learners often failing to draw upon the richness of the opportunities for learning offered (Harri-Augustein and Thomas, 1991). This is due to individual-differences, job/job - characteristics, context and environment factors (Morrison and Brantner, 1992). In particular, many practitioners work in an environment that does not encourage them to think about their practise and how it might be made more effective (Mumford, 1981). Fortunately, learners are most influenced by their peers (Freedman, 1967), as the majority of managers are unlikely to be aware of the impact of learning style on their subordinates, and consequently on the ability of subordinates to learn from and with them. Very rarely are the specific opportunities for particular learning identified in advance, reviewed beforehand with individuals, or subsequently reviewed and discussed (Mumford, 1991).

Ideally, it is said that an organisational culture climate approach is needed, in which an organisation encourages learning by encouraging managers to identify their own learning needs and setting challenging learning goals; encouraging managers to experiment; providing opportunities for learning both on and off the job; giving on-the-spot feedback; allowing time for managers to review, conclude and plan learning activities, and tolerating some mistakes, provided managers try to learn from them (Mumford, 1986). Additionally the "ideal" working situation: "... has jobs that grow and expand; takes action to meet development needs;... allows people to decide how to meet their objectives; has collaborative processes for setting objectives; diagnoses the causes of problems; encourages people to be open about their problems;... welcomes new ideas; constantly changes; has top management who are actively involved in training and development

Lowe, D and Skitmore, M (2011) 'The learning climate of chartered quantity surveying practices', Australasian Journal of Construction Economics and Building, 11 (4) 1-20 
activities;... provides opportunities to use new skills;... constantly strives to improve quality; encourages people to aim high; uses task forces and project teams; encourages people to experiment with new ways of doing things; actively supports people's plans to implement something learned on a course" (Honey and Mumford, 1989 p 8).

Several studies have been made of the learning climate of professions such as medicine (e.g., Schultz et al 2004), teaching (e.g., Chou and Lui 2005), nursing (e.g., Chun-Heung 1997, Myrick and Yonge 2001), personnel administration (e.g., Mikkelsen 1998), management (e.g., Ortenblad 2002; Chou et al 2005) and social work (e.g., Barron 2004). The only study to date concerning the learning climate of quantity surveyors examines the effects on performance (Lowe and Skitmore 2007). To date, nothing is known of the details or typology of the learning climate in this context however.

\section{Empirical Study}

\section{Sample}

The population for the investigation was experienced quantity surveyors based within Greater Manchester, central Lancashire and south Lakeland. The area of study was selected as representative of North West England. It was believed that the area represented a relatively homogeneous group. Ultimately, 84 practitioners from 77 organisations took part, representing $45 \%$ of the estimated population of such organisations in the region. All the respondents have experience in providing early stage building price forecasts.

\section{Questionnaire}

The interviewees were required to complete a multi-part questionnaire comprising

- An experience profile of the subjects, which provided information concerning their position within their organisation, length of experience and the size of the organisation.

- A learning climate questionnaire (LCQ), an inventory designed to elicit information on whether the subjects considered their organisation provided an appropriate climate

- A revised randomised version of Kolb's (1985) Learning Style Inventory (LSI - 1985), and

- An approach to learning at work questionnaire (ALQ)

The LCQ required the subjects to rate fifteen pairs of statements on a five-point semantic differential scale. The chosen statements were derived from Pedler et al's (1991) measuring the quality of your learning climate; Honey and Mumford's (1989) work situation items and Mumford's (1980) ways in which supervisors can improve the learning climate. The original scoring method of Kolb's LSI - 1985 was replaced by a four-point agreement scale. The rationale for this was to remove the ipsative nature of the inventory. The choice of a fourpoint scale was dictated by a desire to force a choice between agreement/disagreement with each item. The ALQ required the subjects to rate the strength of their agreement to twentyfour statements on a five-point agreement scale. The statements were derived from Kolb et al's guide for analysis of personal problem solving processes (Kolb et al. 1979); Kolb's adaptive competencies and work abilities (Kolb 1984); Mumford's skills involved in effective learning behaviour and the rational approach to learning (Mumford 1980); Honey and Mumford's knowledge and skills items and abilities of the ideal learner (Honey and Mumford 1989); Richardson's Approaches to studying questionnaire (Richardson 1990); Smith's post project analysis form (Smith 1982) and Gibbs' abilities associated with each stage of the learning cycle (Gibbs 1988).

\section{Analysis}

Descriptive statistics were calculated for the measures of time in the profession, position in the organisation and size of the organisation. Likewise, descriptive statistics were calculated 
for each item of the LCQ, which were then ranked based on the mean score. A three ("k") factor analysis was performed for the LCQ and factor scores generated. Each item of the $L C Q$, a summary variable and the three factor scores were analysed for differences, by means of ' $t$ ' tests and its comparable non-parametric test, between subgroups based on position within the organisation, size of practice and the total size of organisation. They were also analysed for differences between 4 subgroups based on time/size of practice interaction using one-way analysis of variance (ANOVA) and its comparable non-parametric test. The mean, standard deviation, and internal consistency coefficients (using Cronbach's alpha and the Spearman-Brown split-half reliability test) were calculated for each subscale of Kolb's revised LSI - 1985. A six ("k") factor analysis was performed for the ALQ and factor scores generated. Each item of the LCQ and the four summary variables were correlated with measures of length of experience, the size of the organisation, the quantity surveyors' ability, the subscales of Kolb's LSI - 1985 and the ALQ factor scores. Partial correlation coefficients were calculated between the four LCQ summary variables and measures of the length of experience, controlling for size of the practice and then again controlling for the size of the organisation. Similarly partial correlation coefficients were also calculated between the four LCQ summary variables and measures of the size of the practice/organisation, controlling for time in the profession. Separate multiple regression analyses were undertaken with the LCQ summary variable and the three factor scores as the dependent variable.

\section{Findings \\ Perceptions of the Learning Climate}

\section{LCQ summary variables}

Initially, principal components extraction with varimax rotation was used to determine the underlying dimensions of the 15 items of the LCQ. The number of factors extracted dictated by Kaiser's criterion. This produced a three-factor solution, while a scree plot indicated that the true number of factors lay between two and four factors. Two, three and four factor solutions were carried out, and after inspecting the factor loadings matrices the three-factor solution was computed. The initial eigenvalues ranged from 5.71 for factor one to 1.13 for factor three and the solution accounted for $55.36 \%$ of the variance. The final solution was generated using principal factor extraction with an oblique (Oblimin) rotation. The threefactor solution accounts for $45.1 \%$ of the total variance in the LCQ. The internal consistencies of the three factors were measured by the squared multiple correlations and found to be internally consistent. Variables were ordered and grouped by size and interpretive labels suggested.

Factor one 'Human Support' is associated with items the 8, 10, 4, 11, 5, 7, 6, and 9: 'People are very willing and supportive; pleasure is taken in the success of others'; 'The organisation is an open and friendly place'; 'People are usually ready to give their views and pass on information'; 'Discussion of problems is actively encouraged'; 'People are recognised for good work and rewarded for effort and learning'; 'If people develop a new skill or technique there is plenty of opportunity to use it'; 'People manage themselves and their work; there is great emphasis on taking personal responsibility'; 'Constructive feedback is often provided about your performance'. Factor two 'Staff Development Systems' is associated with the items 3, 1 and 2: 'There is a systematic process for identifying individual development needs'; 'There are lots of resources; development facilities are very good'; 'People are encouraged to learn at all times and to extend themselves and their knowledge'. Factor three 'Working Practices' is associated with the items 14, 15, 13, and 12: 'Accepts that some estimates will prove to be inadequate'; 'Explicitly deals with risk and uncertainty'; 'Working practices and structures are constantly under review'; 'High standards are a goal to be achieved'. Three factor scores were generated using the regression method. The validity of these dimensions is supported by Vandenput (1973), as discussed earlier.

Lowe, D and Skitmore, M (2011) 'The learning climate of chartered quantity surveying practices', Australasian Journal of Construction Economics and Building, 11 (4) 1-20 
Additionally, a weighted average LCQ summary variable (LCQ) was created.

\section{Descriptive statistics}

The alpha reliability estimate for the total scale was 0.86 , while the split-half reliability estimate was 0.82 . This suggests the inventory is internally consistent. Frequencies and summary statistics for the fifteen statements used in the LCQ are presented in Table 1, ranked by their mean scores.

\begin{tabular}{|c|c|c|c|c|c|c|c|c|c|c|}
\hline $\mathbf{Q}$ & & 4 & 3 & 2 & 1 & 0 & & $\begin{array}{l}\text { Med } \\
\text {-ian }\end{array}$ & Mean & SD \\
\hline 10 & $\begin{array}{l}\text { The organisation is an } \\
\text { open and friendly place }\end{array}$ & 38 & 31 & 8 & 6 & 1 & $\begin{array}{l}\text { There is little openness and } \\
\text { support; the organisation is } \\
\text { cold and insular }\end{array}$ & 3 & 3.18 & 0.96 \\
\hline 6 & $\begin{array}{l}\text { People manage } \\
\text { themselves and their } \\
\text { work; there is great } \\
\text { emphasis on taking } \\
\text { personal responsibility }\end{array}$ & 32 & 38 & 12 & 1 & 1 & $\begin{array}{l}\text { People conform to rules and } \\
\text { standards at all times - no } \\
\text { personal responsibility is taken } \\
\text { or given }\end{array}$ & 3 & 3.18 & 0.81 \\
\hline 11 & $\begin{array}{l}\text { Discussion of problems is } \\
\text { actively encouraged }\end{array}$ & 34 & 30 & 12 & 7 & 1 & 'People don't have problems' & 3 & 3.06 & 1.00 \\
\hline 12 & $\begin{array}{l}\text { High standards are a goal } \\
\text { to be achieved }\end{array}$ & 33 & 22 & 22 & 6 & 1 & $\begin{array}{l}\text { High standards are } \\
\text { compulsory }\end{array}$ & 3 & 2.95 & 1.03 \\
\hline 4 & $\begin{array}{l}\text { People are usually ready } \\
\text { to give their views and } \\
\text { pass on information }\end{array}$ & 19 & 46 & 15 & 4 & 0 & $\begin{array}{l}\text { People tend to keep their } \\
\text { feelings to themselves; are } \\
\text { secretive and information is } \\
\text { hoarded }\end{array}$ & 3 & 2.95 & 0.77 \\
\hline 2 & $\begin{array}{l}\text { People are encouraged to } \\
\text { learn at all times and to } \\
\text { extend themselves and } \\
\text { their knowledge }\end{array}$ & 20 & 38 & 20 & 5 & 1 & $\begin{array}{l}\text { There is little encouragement } \\
\text { to learn; there are low } \\
\text { expectations of people in } \\
\text { terms of new skills and abilities }\end{array}$ & 3 & 2.85 & 0.90 \\
\hline 8 & $\begin{array}{l}\text { People are very willing } \\
\text { and supportive; pleasure } \\
\text { is taken in the success of } \\
\text { others }\end{array}$ & 21 & 35 & 21 & 6 & 1 & $\begin{array}{l}\text { People don't support each } \\
\text { other; there is an unwillingness } \\
\text { to pool or share information }\end{array}$ & 3 & 2.82 & 0.93 \\
\hline 5 & $\begin{array}{l}\text { People are recognised for } \\
\text { good work and rewarded } \\
\text { for effort and learning }\end{array}$ & 18 & 33 & 22 & 7 & 4 & $\begin{array}{l}\text { People's successes are } \\
\text { ignored but blame is readily } \\
\text { attributed }\end{array}$ & 3 & 2.64 & 1.06 \\
\hline 7 & $\begin{array}{l}\text { If people develop a new } \\
\text { skill or technique there is } \\
\text { plenty of opportunity to } \\
\text { use it }\end{array}$ & 15 & 30 & 32 & 6 & 1 & $\begin{array}{l}\text { If people develop a new skill or } \\
\text { technique there are few } \\
\text { opportunities to use it }\end{array}$ & 3 & 2.62 & 0.90 \\
\hline 13 & $\begin{array}{l}\text { Working practices and } \\
\text { structures are constantly } \\
\text { under review }\end{array}$ & 18 & 28 & 25 & 11 & 2 & $\begin{array}{l}\text { Working practices and } \\
\text { structures are static }\end{array}$ & 3 & 2.58 & 1.04 \\
\hline 14 & $\begin{array}{l}\text { Accepts that some } \\
\text { estimates will prove to be } \\
\text { inadequate }\end{array}$ & 10 & 38 & 26 & 8 & 2 & $\begin{array}{l}\text { Does not accept inadequate } \\
\text { estimates }\end{array}$ & 3 & 2.55 & 0.91 \\
\hline 15 & $\begin{array}{l}\text { Explicitly deals with risk } \\
\text { and uncertainty }\end{array}$ & 14 & 32 & 27 & 7 & 4 & Avoids risk and uncertainty & 3 & 2.54 & 1.02 \\
\hline 9 & $\begin{array}{l}\text { Constructive feedback is } \\
\text { often provided about your } \\
\text { performance }\end{array}$ & 7 & 27 & 33 & 15 & 2 & $\begin{array}{l}\text { Constructive feedback is rarely } \\
\text { provided about your } \\
\text { performance }\end{array}$ & 2 & 2.26 & 0.93 \\
\hline 3 & $\begin{array}{l}\text { There is a systematic } \\
\text { process for identifying } \\
\text { individual development } \\
\text { needs }\end{array}$ & 7 & 20 & 24 & 26 & 7 & $\begin{array}{l}\text { The identification of } \\
\text { development needs is left to } \\
\text { the individual }\end{array}$ & 2 & 1.93 & 1.11 \\
\hline 1 & $\begin{array}{l}\text { There are lots of } \\
\text { resources; development } \\
\text { facilities are very good }\end{array}$ & 4 & 21 & 29 & 22 & 8 & $\begin{array}{l}\text { Training packages, resources } \\
\text { and equipment are limited }\end{array}$ & 2 & 1.89 & 1.04 \\
\hline
\end{tabular}

Table 1 Frequencies, means and standard deviations of individual items of the Learning Climate Questionnaire (LCQ) [n = 84] 
This indicates that the working environment within quantity surveying organisations is perceived to be supportive in terms of Human Support. Those statements given a high rating included: "The organisation is an open and friendly place"; "People manage themselves and their work; there is great emphasis on taking personal responsibility"; "Discussion of problems is actively encouraged"; "High standards are a goal to be achieved" and "People are usually ready to give their views and pass on information". This finding is important as learning within an environment requires a human communications network or society (Rogers, $1986 \mathrm{pp}$ 54-55), relates to the social context within which learning takes place (Lovell, 1980 p 13), while Snell (1992) considers the main source of 'pain' in learning to be the prevailing organisational ethos of competitive individualism. Further, Freedman (1967) states that learners are more influenced by their peers than by any other factor within their learning environment.

The results also suggested that the working environment was considered to be less supportive in terms of Staff Development Systems. Ogunlana (1991) has suggested that design offices should set up a formal system for self-evaluation that promotes learning through constructive use of process and outcome feedback. The low ratings given to a systematic process for identifying individual development needs within organisations and the provision of constructive feedback suggest that surveying organisations either know that this is not necessary or still have to finds ways to effectively implement this.

\section{Differences in Perceptions of the Learning Climate based on the Practitioner's Position in the Organisation}

\section{Descriptive statistics}

40 of the respondents were partners or director of their organisation (47.6\%), 20 were associates (23.8\%), 20 were principal or senior quantity surveyors (23.8\%) and 4 were quantity surveyors (4.8\%) - indicating a preponderance of subjects holding senior positions within their organisation. All the practitioners were of an appropriate level of experience and seniority, thus, producing a homogenous sample (Rosenthal and Rosnow, 1991) sufficiently large enough to allow statistical analysis.

\section{Tests for differences}

The items of the LCQ and the four summary variables were tested for differences between subgroups based on the position of the practitioner within their organisation: quantity surveying practitioners (Pos. $1 ; n=44$ ) and partners or directors (Pos. $2 ; n=40$ ). The results of this analysis are presented in Table 2.

Very highly significant differences (at the $0.1 \%$ level) were established between the two subgroups for the Human Support and Working Practices factor scores and the LCQ summary variable. Additionally, significant differences exist for seven of the eight LCQ items associated with Human Support and three of the four items associated with Working Practices. For all the significant items, the partners/directors' mean scores were higher than those of the employees.

The findings suggest that as individuals rise in the hierarchy of an organisation their perception of its ability to provide an appropriate learning climate increases. The reasons for this could be due to: a sense of loyalty to the organisation (the organisation has enabled them to rise to the top); an increased expectation by employees for the organisation to provide an appropriate learning environment; because the 'older' practitioners have progressed beyond the major learning events of their career development and are, therefore, less likely to be critical of the organisation's learning environment; or simply that the climate, being 'designed' by the more established staff, is just better suited to their needs. However, there appears to be agreement between both subgroups concerning the 
provision of Staff Development Systems, particularly relating to the identification of needs and the provision of learning resources.

\begin{tabular}{|c|c|c|c|c|c|c|}
\hline Item & & $\begin{array}{l}\text { Position in } \\
\text { Organisation }\end{array}$ & $\begin{array}{c}\text { Size of } \\
\text { Practice }\end{array}$ & $\begin{array}{l}\text { Total size of } \\
\text { Organisation }\end{array}$ & \multicolumn{2}{|c|}{$\begin{array}{l}\text { Time/Size of } \\
\text { Practice } \\
\text { Interaction }\end{array}$} \\
\hline \multirow[t]{2}{*}{ 10. Organisation (HS) } & $\mathbf{T}$ & $-4.636^{* * *}$ & $2.461^{*}$ & $3.244^{\star \star}$ & $\mathbf{F}$ & $3.164^{*}$ \\
\hline & $z$ & $-4.187^{\star * *}$ & $2.891^{\star \star}$ & $3.060^{\star \star}$ & $x^{2}$ & $11.316^{\star *}$ \\
\hline \multirow[t]{2}{*}{ 6. Personal responsibility (HS) } & $\mathbf{T}$ & $-2.485^{*}$ & $2.654^{* \star}$ & $2.062^{*}$ & $\mathbf{F}$ & $3.023^{*}$ \\
\hline & z & $-2.430^{*}$ & $3.296^{\star \star \star}$ & $2.519^{*}$ & $x^{2}$ & $14.608^{* *}$ \\
\hline \multirow[t]{2}{*}{ 11. Problems (HS) } & $\mathbf{T}$ & $-4.934^{* * *}$ & 0.544 & 1.657 & $\mathbf{F}$ & 1.071 \\
\hline & $z$ & $-4.456^{* * *}$ & 0.899 & 1.783 & $x^{2}$ & 5.214 \\
\hline \multirow[t]{2}{*}{ 12. High standards (WP) } & $\mathbf{T}$ & $-4.446^{\star * *}$ & 0.634 & 1.062 & $\mathbf{F}$ & 1.067 \\
\hline & $z$ & $-4.217^{* * *}$ & 0.824 & 1.341 & $x^{2}$ & 3.204 \\
\hline \multirow[t]{2}{*}{ 4. People - information (HS) } & $\mathbf{T}$ & -1.681 & $2.312^{*}$ & $2.944^{* *}$ & $\mathbf{F}$ & $2.865^{*}$ \\
\hline & z & -1.673 & $2.521^{*}$ & $2.917^{* \star}$ & $x^{2}$ & $9.111^{*}$ \\
\hline \multirow[t]{2}{*}{ 2. Encouragement to learn (SDS) } & $\mathbf{T}$ & $-2.043^{*}$ & 0.362 & 0.605 & $\mathbf{F}$ & 0.800 \\
\hline & $z$ & -1.857 & 0.539 & 0.658 & $x^{2}$ & 2.027 \\
\hline \multirow[t]{2}{*}{ 8. Support (HS) } & $\mathbf{T}$ & $-3.841^{* * *}$ & $2.533^{*}$ & $2.797^{\star *}$ & $\mathbf{F}$ & $2.706^{*}$ \\
\hline & $z$ & $-3.581^{* \star *}$ & $2.689^{* *}$ & $2.953^{\star *}$ & $x^{2}$ & $9.708^{*}$ \\
\hline \multirow[t]{2}{*}{ 5. Recognition of work (HS) } & $\mathbf{T}$ & $-4.172^{\star \star \star}$ & $2.323^{\star}$ & 1.811 & $\mathbf{F}$ & 1.760 \\
\hline & $z$ & $-3.847^{* * *}$ & $2.165^{*}$ & $1.978^{*}$ & $x^{2}$ & 4.847 \\
\hline \multirow[t]{2}{*}{ 7. New skills (HS) } & $\mathbf{T}$ & $-3.119^{* *}$ & 0.481 & 0.000 & $\mathbf{F}$ & 0.605 \\
\hline & $z$ & $-2.895^{* *}$ & 0.573 & 0.066 & $x^{2}$ & 2.925 \\
\hline \multirow[t]{2}{*}{ 13. Working practices (WP) } & $\mathbf{T}$ & -1.854 & -1.152 & 0.104 & $\mathbf{F}$ & 0.843 \\
\hline & $z$ & -1.742 & -1.065 & -0.270 & $x^{2}$ & 2.611 \\
\hline \multirow[t]{2}{*}{ 14. Estimates (WP) } & $\mathbf{T}$ & $-3.942^{* * *}$ & 0.717 & 0.477 & $\mathbf{F}$ & 0.499 \\
\hline & $z$ & $-3.657^{* * *}$ & 0.841 & 0.602 & $x^{2}$ & 1.696 \\
\hline \multirow[t]{2}{*}{ 15. Risk \& uncertainty (WP) } & $\mathbf{T}$ & $-2.328^{*}$ & 0.531 & 0.959 & $\mathbf{F}$ & 0.832 \\
\hline & $z$ & $-2.324^{*}$ & 0.691 & 0.949 & $x^{2}$ & 2.394 \\
\hline \multirow[t]{2}{*}{ 9. Feedback (HS) } & $\mathbf{T}$ & $-2.537^{*}$ & 0.466 & 1.900 & $\mathbf{F}$ & 0.919 \\
\hline & $z$ & $-2.341^{*}$ & 0.288 & 1.872 & $x^{2}$ & 2.400 \\
\hline \multirow[t]{2}{*}{ 3. Identification of needs (SDS) } & $\mathbf{T}$ & -0.763 & $-2.656^{\star *}$ & $-3.585^{\star \star *}$ & $\mathbf{F}$ & $5.195^{\star \star}$ \\
\hline & $z$ & -0.635 & $-2.608^{* *}$ & $-3.372^{* * *}$ & $x^{2}$ & $13.023^{* *}$ \\
\hline \multirow[t]{2}{*}{ 1. Resources (SDS) } & $\mathbf{T}$ & 1.221 & $-3.455^{\star \star \star}$ & $-3.203^{* *}$ & $\mathbf{F}$ & $4.832^{* *}$ \\
\hline & $\mathbf{z}$ & -1.285 & $-3.117^{\star *}$ & $-2.973^{* \star}$ & $x^{2}$ & $11.683^{* *}$ \\
\hline \multirow[t]{2}{*}{ LCQ Summary variable (LCQ) } & $\mathbf{T}$ & $-4.260^{\star * *}$ & -0.164 & 0.224 & $\mathbf{F}$ & 1.213 \\
\hline & $z$ & $-3.735^{\star * *}$ & -0.076 & -0.358 & $x^{2}$ & 5.686 \\
\hline \multirow[t]{2}{*}{ Human Support (HS) } & $\mathbf{T}$ & $-5.203^{* * *}$ & $2.758^{\star *}$ & $3.381^{* \star *}$ & $\mathbf{F}$ & $3.775^{*}$ \\
\hline & $\mathbf{z}$ & $-4.532^{* * *}$ & $3.024^{* \star}$ & $3.364^{* * *}$ & $x^{2}$ & $12.729^{* *}$ \\
\hline \multirow[t]{2}{*}{ Working Practices (WP) } & $\mathbf{T}$ & $-5.621^{* * *}$ & 1.017 & 1.377 & $\mathbf{F}$ & 0.952 \\
\hline & $z$ & $-5.150^{* * *}$ & -1.279 & -1.744 & $x^{2}$ & 6.036 \\
\hline \multirow[t]{2}{*}{ Staff Development Systems (SDS) } & $\mathbf{T}$ & -0.793 & $-2.899^{* *}$ & $-2.901^{* *}$ & $\mathbf{F}$ & $4.513^{\star *}$ \\
\hline & $z$ & -0.421 & $-2.791^{* *}$ & $-2.872^{\star *}$ & $x^{2}$ & $13.167^{* *}$ \\
\hline
\end{tabular}

Table 2 ANOVA and tests for differences for Learning Climate Questions $(n=84)$

${ }^{* * *}=p \leq 0.001^{* *}=p \leq 0.01^{*}=p \leq 0.05$ 't' = t-test for Independent Samples, ' $z$ ' = Mann-Whitney U - Wilcoxon Rank Sum W Test, F = F Ratio One-way Analysis of Variance, $\quad$ x2 = Chi-Square Kruskal-Wallis 1-Way Anova

Lowe, D and Skitmore, M (2011) 'The learning climate of chartered quantity surveying practices', Australasian Journal of Construction Economics and Building, 11 (4) 1-20 


\section{Relationships between the Learning Climate and Measures of the Length of Experience}

\section{Descriptive statistics}

The length of time the practitioners had been providing general cost advice was a mean of 17.8 years (SD 6.9). This is comparable with the length of corporate membership of the Royal Institution of Chartered Surveyors (RICS). The results (Table 3) suggest that quantity surveyors specialise after approximately 4 years general estimating experience. This is illustrated by a median difference of 4 years and a mean difference of 3.64 years experience respectively.

\begin{tabular}{|l|c|c|c|c|c|c|}
\hline & Mode & Median & Mean & SD & Kurtosis & Skewness \\
\hline Generally & 20 & 16 & 16.67 & 7.79 & -0.07 & 0.45 \\
\hline $\begin{array}{l}\text { Area(s) of } \\
\text { specialism }\end{array}$ & 20 & 12 & 13.03 & 7.20 & -0.65 & 0.49 \\
\hline RICS Membership & 8 & 16 & 16.69 & 9.02 & -1.04 & 0.25 \\
\hline
\end{tabular}

Table 3 Modes, medians, means and standard deviations for the length of experience $(n=84)$ and RICS membership ( $n=73$ )

\section{Correlations}

The items of the LCQ and the four summary variables were correlated with three measures of the length of experience of the practitioners: the number of years as an estimator, the number of years of specialism within estimating and the number of years as a corporate member of the RICS. Pearson's 'r' and Spearman's 'rs' correlation matrices are presented in Table 4.

The results indicate that the practitioners' perception of their organisation's ability to provide an appropriate learning climate, in terms of Human Support (the factor score and the LCQ items associated with personal responsibility, the introduction of new skills, and the discussion of problems) and to a lesser extent for Working Practices (the factor score and the item related to high standards) increase significantly with measures of time in the profession. However, there appears to be no indication of a relationship between time in the profession and the provision of Staff Development Systems.

\section{Relationships between the Learning Climate and Measures of the Size of the Practice}

\section{Descriptive statistics}

To investigate the relationship between the learning climate of an organisation and its size, both the size of the practitioner's practice and the size of their total organisation in terms of the number of professional/technical staff were obtained. The results are presented in Table 5 .

\section{Correlations}

The items of the LCQ and the four summary variables were also correlated with two measures of the size of the practice (the practitioners' office) and the size of the practitioner's organisation as a whole. Pearson's ' $r$ ' and Spearman's 'rs' correlation matrices are presented in Table 4.

The results indicate that the Staff Development Systems factor score (and the LCQ items associated with the provision of learning resources and the identification of needs) 
correlated significantly and positively with both measures of size. However, the Human Support factor score (and the items linked to the friendliness of the organisation, personal responsibility, people sharing information, support from colleagues, discussion of problems, and recognition of work) were found to correlate significantly and negatively with measures of size.

\begin{tabular}{|c|c|c|c|c|c|c|}
\hline & & $\begin{array}{l}\text { No years } \\
\text { generally }\end{array}$ & $\begin{array}{l}\text { No years } \\
\text { specialism }\end{array}$ & $\begin{array}{l}\text { No } \\
\text { Years } \\
\text { in } \\
\text { RICS }\end{array}$ & $\begin{array}{c}\text { Size of } \\
\text { practice }\end{array}$ & $\begin{array}{c}\text { Size of } \\
\text { total } \\
\text { Organisati } \\
\text {-on }\end{array}$ \\
\hline & & $\mathrm{n}=84$ & $\mathrm{n}=84$ & $n=73$ & $\mathrm{n}=84$ & $n=74$ \\
\hline \multirow[t]{2}{*}{ 10. Organisation (HS) } & $P^{\prime} r_{s}{ }^{\prime}$ & 0.130 & $0.216^{*}$ & 0.091 & $-0.274^{*}$ & $-0.287^{*}$ \\
\hline & $S^{\prime} r_{s}{ }^{\prime}$ & 0.112 & 0.161 & 0.053 & $-0.290^{\star *}$ & $-0.308^{* *}$ \\
\hline \multirow{2}{*}{ 6. Personal responsibility (HS) } & $P^{\prime} r_{s}{ }^{\prime}$ & $0.252^{*}$ & $0.237^{*}$ & $0.259^{*}$ & -0.168 & -0.085 \\
\hline & $S^{\prime} r_{s}{ }^{\prime}$ & $0.296^{* *}$ & $0.272^{*}$ & $0.285^{*}$ & $-0.348^{* * *}$ & -0.153 \\
\hline \multirow[t]{2}{*}{ 11. Problems (HS) } & $P^{\prime} r_{s}{ }^{\prime}$ & 0.206 & 0.198 & 0.184 & $-0.253^{*}$ & -0.190 \\
\hline & $S^{\prime} r_{s}{ }^{\prime}$ & $0.235^{*}$ & $0.232^{*}$ & 0.172 & -0.112 & -0.181 \\
\hline \multirow[t]{2}{*}{ 12. High standards (WP) } & $P^{\prime} r_{s}{ }^{\prime}$ & 0.151 & $0.299^{* *}$ & 0.111 & -0.149 & -0.075 \\
\hline & $S^{\prime} r_{s}{ }^{\prime}$ & 0.196 & $0.281^{* *}$ & 0.116 & -0.163 & -0.119 \\
\hline \multirow[t]{2}{*}{ 4. People - information (HS) } & $P^{\prime} r_{s}{ }^{\prime}$ & 0.177 & 0.195 & 0.154 & -0.050 & $-0.239^{*}$ \\
\hline & $S^{\prime} r_{s}{ }^{\prime}$ & 0.168 & 0.186 & 0.136 & -0.208 & $-0.336^{* *}$ \\
\hline \multirow[t]{2}{*}{ 2. Encouragement to learn (SDS) } & $P^{\prime} r_{s}{ }^{\prime}$ & 0.049 & 0.081 & 0.052 & -0.047 & -0.011 \\
\hline & $S^{\prime} r_{s}{ }^{\prime}$ & 0.031 & 0.089 & 0.049 & 0.028 & 0.016 \\
\hline \multirow[t]{2}{*}{ 8. Support (HS) } & $P^{\prime} r_{s}{ }^{\prime}$ & 0.172 & 0.164 & 0.176 & -0.139 & -0.121 \\
\hline & $S^{\prime} r_{s}{ }^{\prime}$ & 0.166 & 0.163 & 0.193 & $-0.242^{*}$ & $-0.230^{*}$ \\
\hline \multirow[t]{2}{*}{ 5. Recognition of work (HS) } & $P^{\prime} r_{s}{ }^{\prime}$ & 0.153 & 0.147 & 0.104 & -0.176 & -0.062 \\
\hline & $S^{\prime} r_{s}{ }^{\prime}$ & 0.098 & 0.093 & 0.065 & $-0.228^{*}$ & -0.161 \\
\hline \multirow[t]{2}{*}{ 7. New skills (HS) } & $P^{\prime} r_{s}{ }^{\prime}$ & $0.253^{*}$ & $0.225^{*}$ & 0.157 & -0.089 & -0.077 \\
\hline & $S^{\prime} r_{s}{ }^{\prime}$ & $0.236^{*}$ & $0.216^{*}$ & 0.156 & -0.032 & 0.022 \\
\hline \multirow[t]{2}{*}{ 13. Working practices (WP) } & $P^{\prime} r_{s}{ }^{\prime}$ & 0.179 & 0.147 & 0.051 & -0.035 & 0.012 \\
\hline & $S^{\prime} r_{s}{ }^{\prime}$ & 0.168 & 0.144 & 0.059 & 0.016 & -0.063 \\
\hline \multirow[t]{2}{*}{ 14. Estimates (WP) } & $P^{\prime} r_{s}^{\prime}$ & 0.109 & 0.088 & 0.069 & -0.006 & 0.018 \\
\hline & $S^{\prime} r_{s}{ }^{\prime}$ & 0.134 & 0.109 & 0.078 & -0.056 & -0.107 \\
\hline \multirow[t]{2}{*}{ 15. Risk \& uncertainty (WP) } & $P^{\prime} r_{s}^{\prime}$ & 0.021 & 0.017 & -0.072 & -0.115 & 0.078 \\
\hline & $S^{\prime} r_{s}{ }^{\prime}$ & 0.055 & 0.070 & -0.067 & -0.139 & -0.017 \\
\hline \multirow[t]{2}{*}{ 9. Feedback (HS) } & $P^{\prime} r_{s}{ }^{\prime}$ & 0.040 & 0.065 & -0.021 & -0.188 & -0.163 \\
\hline & $S^{\prime} r_{s}{ }^{\prime}$ & 0.033 & 0.054 & -0.033 & -0.011 & -0.145 \\
\hline \multirow[t]{2}{*}{ 3. Identification of needs (SDS) } & $P^{\prime} r_{s}{ }^{\prime}$ & -0.017 & -0.035 & -0.046 & 0.010 & $0.358^{* *}$ \\
\hline & $S^{\prime} r_{s}{ }^{\prime}$ & -0.026 & -0.059 & -0.049 & $0.248^{*}$ & $0.324^{* *}$ \\
\hline \multirow[t]{2}{*}{ 1. Resources (SDS) } & $P^{\prime} r_{s}{ }^{\prime}$ & -0.175 & -0.186 & -0.140 & $0.225^{*}$ & $0.351^{\star \star}$ \\
\hline & $S^{\prime} r_{s}{ }^{\prime}$ & -0.176 & -0.180 & -0.154 & $0.406^{\star \star *}$ & $0.396^{\star \star *}$ \\
\hline \multirow[t]{2}{*}{ LCQ Summary variable (LCQ) } & $P^{\prime} r_{s}{ }^{\prime}$ & 0.133 & 0.151 & 0.071 & -0.102 & 0.080 \\
\hline & $S^{\prime} r_{s}{ }^{\prime}$ & 0.119 & 0.165 & 0.044 & -0.000 & 0.029 \\
\hline \multirow[t]{2}{*}{ Human Support (HS) } & $P^{\prime} r_{s}{ }^{\prime}$ & $0.234^{*}$ & $0.257^{*}$ & 0.205 & $-0.233^{*}$ & $-0.252^{*}$ \\
\hline & $S^{\prime} r_{s}{ }^{\prime}$ & 0.213 & $0.234^{*}$ & 0.183 & $-0.288^{* *}$ & $-0.319^{* *}$ \\
\hline \multirow[t]{2}{*}{ Working Practices (WP) } & $P^{\prime} r_{s}{ }^{\prime}$ & $0.219^{*}$ & $0.216^{*}$ & 0.136 & -0.175 & -0.049 \\
\hline & $S^{\prime} r_{s}{ }^{\prime}$ & $0.247^{*}$ & $0.259^{*}$ & 0.139 & -0.178 & -0.183 \\
\hline \multirow[t]{2}{*}{ Staff Development Systems (SDS) } & $P^{\prime} r_{s}{ }^{\prime}$ & -0.038 & -0.047 & -0.070 & 0.068 & $0.312^{\star \star}$ \\
\hline & $S^{\prime} r_{s}{ }^{\prime}$ & -0.104 & -0.088 & -0.134 & $0.316^{\star *}$ & $0.350^{\star *}$ \\
\hline
\end{tabular}

Table 4 Correlations between Learning Climate Questions and Number of years experience and size of organisation 


\begin{tabular}{|l|c|c|c|c|c|c|}
\hline & Mode & Median & Mean & SD & Kurtosis & Skewness \\
\hline Size of Practice & 3 & 7.5 & 23.77 & 52.81 & 18.50 & 4.26 \\
\hline $\begin{array}{l}\text { Size of } \\
\text { Organisation }\end{array}$ & 3 & 15.5 & 153.50 & 274.50 & 7.92 & 2.56 \\
\hline
\end{tabular}

Table 5 Modes, medians, means and standard deviations for size of practice $(n=84)$ and total size of organisation $(n=74)$

\section{Tests for differences}

To investigate this further, the items of the LCQ and the four summary variables were also tested for differences between subgroups based on the size of the practice ( $\mathrm{S} 1=$ small size practices, $\mathrm{S} 2$ = large size practices $)$ and the size of the organisation $(\mathrm{O} 1=$ small organisation, $\mathrm{O} 2$ = large organisation). The results of this analysis are presented in Table 2.

Highly significant differences (at the $1 \%$ level) were established between the two subgroups for the Staff Development Systems factor score and the LCQ items associated with the provision of learning resources and the identification of needs. For all the significant items, the mean scores for practitioners in the larger practices (and larger organisations) were significantly higher than those of practitioners in the smaller practices (and smaller organisations).

Highly significant differences (at the $0.1 \%$ and $1 \%$ levels) were established between the two subgroups for the Human Support factor score. Additionally, there were significant differences for the LCQ items linked to the friendliness of the organisation, personal responsibility, people sharing information, support from colleagues, and recognition of work. For all the significant items, the mean scores for practitioners in the smaller practices (and smaller organisations) were significantly higher than those of practitioners in the larger practices (and larger organisations).

Both these analyses suggest that as the size of the organisation increases the individual's perception of its ability to provide an appropriate learning environment in terms of Staff Development Systems also increases. However, the practitioners' assessment of their organisation in terms of Human Support decrease as its size increases. Further, the results indicate no relationship between their perception of Working Practices and the size of their organisation.

\section{Relationships between the Learning Climate and Individual Learning Styles}

\section{Descriptive statistics}

The mean and standard deviations for the LSI - 1985 subscales for the practitioner sample are presented in Table 6 . The alpha reliability estimates for the total sample were similar to those obtained by Geiger et al. (1993), ranging from 0.74 to 0.88 , while the split-half reliability estimates range from 0.80 to 0.92 for the four main subscales scores. This suggests the inventory is internally consistent.

\begin{tabular}{|l|c|c|c|c|c|r|}
\hline & CE & RO & AC & AE & AC - CE & AE - RO \\
\hline MEAN & 32.43 & 32.86 & 36.82 & 40.49 & 4.39 & 7.63 \\
\hline SD & 4.61 & 6.57 & 4.85 & 4.40 & 5.21 & 6.85 \\
\hline $\mathbf{R}_{1}$ & 0.74 & 0.88 & 0.83 & 0.81 & 0.84 & 0.86 \\
\hline $\mathbf{R}_{\mathbf{2}}$ & 0.80 & 0.92 & 0.89 & 0.87 & 0.85 & 0.91 \\
\hline
\end{tabular}

Table 6 Means, Standard Deviations and Reliabilities for Kolb's Learning Style Inventory - 1985 revised subscales $(n=84)$

R1 = Cronbach's Alpha, $\mathrm{R} 2=$ Spearman-Brown split half

Lowe, D and Skitmore, M (2011) 'The learning climate of chartered quantity surveying practices', Australasian Journal of Construction Economics and Building, 11 (4) 1-20 


\section{Correlations}

The items of the LCQ and the four summary variables scores were correlated with the LSI 1985 subscale scores. Pearson's ' $r$ ' and Spearman's 'rs' correlation matrices are presented in Table 7.

\begin{tabular}{|c|c|c|c|c|c|c|c|}
\hline & & $\begin{array}{l}\text { Concrete } \\
\text { Experience }\end{array}$ & $\begin{array}{l}\text { Reflective } \\
\text { Observati } \\
\text {-on }\end{array}$ & $\begin{array}{l}\text { Abstract } \\
\text { Conceptuali } \\
\text {-sation }\end{array}$ & $\begin{array}{l}\text { Active } \\
\text { Experimen } \\
\text { tation }\end{array}$ & AC_CE & AE_RO \\
\hline \multirow[t]{2}{*}{ 10. Organisation (HS) } & $P^{\prime} r_{s}^{\prime}$ & $0.250^{*}$ & -0.009 & 0.100 & -0.075 & -0.128 & -0.039 \\
\hline & $S^{\prime} r_{s}^{\prime}$ & $0.236^{*}$ & -0.055 & 0.094 & 0.013 & -0.054 & 0.029 \\
\hline \multirow{2}{*}{$\begin{array}{l}\text { 6. Personal responsibility } \\
\text { (HS) }\end{array}$} & $P^{\prime} r_{s}^{\prime}$ & -0.018 & -0.201 & -0.035 & -0.015 & -0.017 & 0.184 \\
\hline & $S^{\prime} r_{s}^{\prime}$ & 0.074 & $-0.220^{*}$ & -0.029 & 0.076 & -0.016 & $0.225^{\star}$ \\
\hline \multirow[t]{2}{*}{ 11. Problems (HS) } & $P^{\prime} r_{s}^{\prime}$ & 0.091 & -0.065 & 0.097 & -0.103 & 0.009 & -0.004 \\
\hline & $S^{\prime} r_{s}^{\prime}$ & 0.128 & -0.107 & 0.123 & -0.035 & 0.032 & 0.052 \\
\hline \multirow[t]{2}{*}{ 12. High standards (WP) } & $P^{\prime} r_{s}^{\prime}$ & 0.192 & 0.004 & $0.295^{\star *}$ & $0.304^{* *}$ & 0.105 & 0.191 \\
\hline & $S^{\prime} r_{s}^{\prime}$ & 0.198 & 0.041 & $0.266^{*}$ & $0.284^{* *}$ & 0.090 & 0.172 \\
\hline \multirow[t]{2}{*}{ 4. People - information (HS) } & $P^{\prime} r_{s}^{\prime}$ & 0.161 & -0.079 & -0.025 & -0.067 & -0.166 & 0.033 \\
\hline & $S^{\prime} r_{s}^{\prime}$ & 0.197 & -0.121 & -0.012 & -0.036 & -0.134 & 0.052 \\
\hline \multirow{2}{*}{$\begin{array}{l}\text { 2. Encouragement to learn } \\
\text { (SDS) }\end{array}$} & $P^{\prime} r_{s}^{\prime}$ & 0.060 & -0.043 & 0.085 & -0.081 & 0.026 & -0.011 \\
\hline & $S^{\prime} r_{s}^{\prime}$ & 0.118 & -0.031 & 0.142 & -0.063 & 0.061 & -0.031 \\
\hline \multirow[t]{2}{*}{ 8. Support (HS) } & $P^{\prime} r_{s}^{\prime}$ & 0.080 & -0.114 & -0.074 & -0.058 & -0.139 & 0.073 \\
\hline & $S^{\prime} r_{s}^{\prime}$ & 0.144 & -0.152 & -0.032 & -0.020 & -0.123 & 0.099 \\
\hline \multirow[t]{2}{*}{ 5. Recognition of work (HS) } & $P^{\prime} r_{s}^{\prime}$ & 0.140 & 0.055 & 0.058 & -0.055 & -0.070 & -0.088 \\
\hline & $S^{\prime} r_{s}^{\prime}$ & 0.186 & 0.036 & 0.088 & -0.001 & -0.014 & -0.079 \\
\hline \multirow[t]{2}{*}{ 7. New skills (HS) } & $P^{\prime} r_{s}^{\prime}$ & 0.045 & 0.011 & 0.113 & -0.004 & 0.065 & -0.013 \\
\hline & $S^{\prime} r_{s}^{\prime}$ & 0.081 & 0.002 & 0.162 & 0.004 & 0.071 & -0.022 \\
\hline \multirow[t]{2}{*}{ 13. Working practices (WP) } & $P^{\prime} r_{s}^{\prime}$ & 0.210 & 0.163 & 0.168 & 0.045 & -0.029 & -0.128 \\
\hline & $S^{\prime} r_{s}^{\prime}$ & $0.256^{*}$ & 0.159 & 0.170 & 0.078 & -0.052 & -0.128 \\
\hline \multirow[t]{2}{*}{ 14. Estimates (WP) } & $P^{\prime} r_{s}^{\prime}$ & $0.225^{\star}$ & 0.122 & 0.085 & 0.185 & -0.120 & 0.002 \\
\hline & $S^{\prime} r_{s}^{\prime}$ & $0.262^{*}$ & 0.120 & 0.096 & $0.231^{*}$ & -0.180 & 0.001 \\
\hline \multirow[t]{2}{*}{ 15. Risk \& uncertainty (WP) } & $P^{\prime} r_{s}^{\prime}$ & -0.057 & 0.038 & 0.005 & 0.038 & 0.055 & -0.013 \\
\hline & $S^{\prime} r_{s}^{\prime}$ & -0.036 & 0.010 & 0.028 & 0.024 & 0.105 & -0.019 \\
\hline \multirow[t]{2}{*}{ 9. Feedback (HS) } & $P^{\prime} r_{s}^{\prime}$ & -0.130 & 0.108 & 0.088 & -0.070 & 0.197 & -0.149 \\
\hline & $S^{\prime} r_{s}^{\prime}$ & -0.065 & 0.116 & 0.042 & -0.070 & 0.196 & -0.172 \\
\hline \multirow{2}{*}{$\begin{array}{l}\text { 3. Identification of needs } \\
\text { (SDS) }\end{array}$} & $P^{\prime} r_{s}^{\prime}$ & 0.058 & 0.159 & 0.130 & 0.121 & 0.070 & -0.075 \\
\hline & $S^{\prime} r_{s}^{\prime}$ & 0.011 & 0.125 & 0.149 & 0.100 & 0.056 & -0.089 \\
\hline \multirow[t]{2}{*}{ 1. Resources (SDS) } & $P^{\prime} r_{s}{ }^{\prime}$ & 0.190 & 0.128 & -0.047 & -0.057 & -0.212 & -0.159 \\
\hline & $S^{\prime} r_{s}{ }^{\prime}$ & 0.173 & 0.138 & -0.001 & -0.057 & -0.201 & -0.189 \\
\hline \multirow{2}{*}{$\begin{array}{ll}\text { LCQ } & \text { Summary } \\
\text { (LCQ) } & \text { variable }\end{array}$} & $P^{\prime} r_{s}^{\prime}$ & 0.193 & 0.086 & 0.143 & 0.054 & -0.037 & -0.048 \\
\hline & $S^{\prime} r_{s}{ }^{\prime}$ & $0.256^{*}$ & 0.089 & 0.207 & 0.148 & -0.026 & -0.029 \\
\hline \multirow[t]{2}{*}{ Human Support (HS) } & $P^{\prime} r_{s}^{\prime}$ & 0.137 & -0.082 & 0.046 & -0.084 & -0.078 & 0.024 \\
\hline & $S^{\prime} r_{s}^{\prime}$ & 0.195 & -0.123 & 0.060 & -0.021 & -0.040 & 0.070 \\
\hline \multirow[t]{2}{*}{ Working Practices (WP) } & $P^{\prime} r_{s}^{\prime}$ & 0.145 & 0.068 & 0.149 & 0.109 & 0.011 & 0.005 \\
\hline & $S^{\prime} r_{s}^{\prime}$ & $0.249^{*}$ & 0.028 & 0.199 & 0.204 & -0.005 & 0.072 \\
\hline \multirow{2}{*}{$\begin{array}{l}\text { Staff Development Systems } \\
\text { (SDS) }\end{array}$} & $P^{\prime} r_{s}^{\prime}$ & 0.135 & 0.166 & 0.113 & 0.021 & -0.015 & -0.146 \\
\hline & $S^{\prime} r_{s}^{\prime}$ & 0.118 & 0.175 & 0.162 & 0.054 & -0.003 & -0.164 \\
\hline
\end{tabular}

Table 7 Correlations between Learning Climate Questions and Kolb's Learning Style Inventory - 1985 revised subscales $(n=84)$

P ' $r$ ' = Pearson's Correlation Coefficients, S 'rs' = Spearman's Correlation Coefficients

The results establish a positive relationship between Concrete Experience and the LCQ summary variable, the Working Practices factor score and the LCQ items associated with

Lowe, D and Skitmore, M (2011) 'The learning climate of chartered quantity surveying practices', Australasian Journal of Construction Economics and Building, 11 (4) 1-20 
the acceptance of errors in estimates, the friendliness of the organisation, and working practices. Likewise, a positive relationship is established between Abstract Conceptualisation and the item related to high standards; and Active Experimentation and the items related to high standards and the acceptance of errors in estimates. Also, a significant but weak negative relationship was found between Reflective Observation and the item related to personal responsibility.

The results suggest a positive relationship between learning styles and the working environment especially those items relating to working practices. An explanation for this could be: the more support, 'Freedom to Learn', an individual receives from their organisation, the more likely they will be to participate in experiential learning. This is especially true for the more active dimensions (Concrete Experience and Active Experimentation), which are apparent to their peers and employers. Overall, however, the lack of significant relationships between many of the LCQ items/factor scores and learning style subscales appears to support Ruble and Stout's (1991) argument that learning styles should be considered as relatively stable personal dispositions, especially when the learning environment remains relatively stable over time.

\section{Relationships between the Learning Climate and Approaches to Learning}

\section{Factor analysis}

Initially, principal components extraction with varimax rotation was used to determine the underlying dimensions of the 24 items of the ALQ. The number of factors extracted dictated by Kaiser's criterion. This produced an eight-factor solution that did not meet the criteria of a simple structure as many variables were complex. A scree plot indicated that the true number of factors lay between five and seven factors. Seven, six and five factor solutions were carried out, and after inspecting the factor loadings matrices the six-factor solution was computed. The initial eigenvalues ranged from 4.91 for factor one to 1.28 for factor six and the solution accounted for $56.8 \%$ of the variance. The final solution was generated using principal factor extraction with an oblique (Oblimin) rotation. The six-factor solution accounts for $43.7 \%$ of the total variance in the ALQ. The internal consistencies of the six factors were measured by the squared multiple correlations. At 0.84 for factor one, 0.78 for factor two, 0.83 for factor three, 0.68 for factor four, 0.77 for factor five and 0.77 for factor six they were internally consistent. Variables were ordered and grouped by size and interpretive labels suggested.

Factor one 'Risk-taking' is associated with the ability to take risks, see connections, adjust quickly, and convert ideas into action and openness. Factor two 'Self-management' is associated with the ability to assess one's own development needs, analyse, and formulate action plans and review performance. Factor three 'Proactivity' or proactive experiential learner is associated with making a conscious effort to learn from experience, question things or investigate new concepts. Factor four 'Insecurity' is associated with the ability to analyse the success of others, share experiences, adjusting quickly but not converting criticism into constructive suggestions for improvement. Factor five 'Passivity' or passive experiential learner is associated with making a conscious effort to learn from experience, listening and adjusting quickly, but not questioning things. Finally, factor six 'Self-confidence' is associated with recognising and adjusting to errors, accepting help or asking questioning. Six factor scores were generated using the regression method.

\section{Correlations}

The items of the LCQ and four summary variables were correlated with the ALQ factor scores. Pearson's ' $r$ ' and Spearman's ' $r_{s}$ ' correlation matrices are presented in Table 8.

The LCQ summary variable correlated significantly and positively with the ALQ factor scores labelled Self-management (at the $0.1 \%$ level) and Self-confidence (at the $5 \%$ level). The

Lowe, D and Skitmore, M (2011) 'The learning climate of chartered quantity surveying practices', Australasian Journal of Construction Economics and Building, 11 (4) 1-20 
Working Practices factor score correlated significantly and positively with the ALQ factor scores Self-management (at the 1\% level), Risk-taking (at the 1\% level) and Self-confidence (at the 5\% level). Also, the Staff Development Systems factor score correlated significantly and positively with the Self-management factor score (at the $5 \%$ level), although none of the LCQ items associated with this dimension correlated significantly with Self-management.

\begin{tabular}{|c|c|c|c|c|c|c|c|}
\hline & & $\begin{array}{c}\text { Risk } \\
\text { Taking }\end{array}$ & $\begin{array}{c}\text { SELF } \\
\text { Manage- } \\
\text { ment }\end{array}$ & $\begin{array}{c}\text { Pro- } \\
\text { actively }\end{array}$ & Insecurity & Passivity & $\begin{array}{c}\text { Self } \\
\text { Confi- } \\
\text { dence }\end{array}$ \\
\hline \multirow[t]{2}{*}{ 10. Organisation (HS) } & $P^{\prime} r_{s}^{\prime}$ & 0.185 & 0.166 & -0.062 & -0.048 & 0.122 & 0.002 \\
\hline & $S^{\prime} r_{s}^{\prime}$ & 0.131 & 0.177 & -0.018 & -0.070 & 0.065 & 0.061 \\
\hline \multirow[t]{2}{*}{ 6. Personal responsibility (HS) } & $P^{\prime} r_{s}^{\prime}$ & 0.210 & -0.012 & 0.017 & 0.016 & 0.007 & $0.266^{*}$ \\
\hline & $S^{\prime} r_{s}{ }^{\prime}$ & $0.277^{\star}$ & 0.029 & 0.106 & -0.023 & 0.025 & $0.313^{* *}$ \\
\hline \multirow[t]{2}{*}{ 11. Problems (HS) } & $P^{\prime} r_{s}^{\prime}$ & 0.118 & 0.064 & -0.157 & 0.034 & 0.105 & 0.060 \\
\hline & $S^{\prime} r_{s}^{\prime}$ & 0.165 & 0.082 & -0.122 & 0.031 & 0.127 & 0.146 \\
\hline \multirow[t]{2}{*}{ 12. High standards (WP) } & $P^{\prime} r_{s}^{\prime}$ & $0.260^{*}$ & $0.221^{*}$ & 0.078 & 0.020 & -0.052 & $0.322^{* *}$ \\
\hline & $S^{\prime} r_{s}^{\prime}$ & $0.277^{*}$ & $0.232^{*}$ & 0.122 & -0.024 & -0.036 & $0.318^{* *}$ \\
\hline \multirow[t]{2}{*}{ 4. People - information (HS) } & $P^{\prime} r_{s}{ }^{\prime}$ & 0.053 & 0.066 & -0.027 & $0.226^{*}$ & 0.025 & 0.036 \\
\hline & $S^{\prime} r_{s}^{\prime}$ & 0.082 & 0.131 & 0.026 & 0.165 & 0.061 & 0.079 \\
\hline \multirow[t]{2}{*}{ 2. Encouragement to learn (SDS) } & $P^{\prime} r_{s}^{\prime}$ & 0.022 & 0.183 & 0.062 & 0.106 & 0.055 & 0.168 \\
\hline & $S^{\prime} r_{s}^{\prime}$ & 0.053 & 0.209 & 0.111 & 0.064 & 0.158 & $0.234^{*}$ \\
\hline \multirow[t]{2}{*}{ 8. Support (HS) } & $P^{\prime} r_{s}^{\prime}$ & -0.064 & 0.032 & -0.197 & 0.151 & 0.202 & $0.250^{*}$ \\
\hline & $S^{\prime} r_{s}^{\prime}$ & -0.006 & 0.065 & -0.153 & 0.140 & $0.240^{*}$ & $0.272^{*}$ \\
\hline \multirow[t]{2}{*}{ 5. Recognition of work (HS) } & $P^{\prime} r_{s}^{\prime}$ & 0.085 & 0.133 & -0.125 & 0.037 & 0.205 & 0.028 \\
\hline & $S^{\prime} r_{s}^{\prime}$ & 0.072 & 0.204 & -0.086 & 0.056 & 0.175 & 0.065 \\
\hline \multirow[t]{2}{*}{ 7. New skills (HS) } & $P^{\prime} r_{s}^{\prime}$ & 0.094 & 0.188 & -0.086 & 0.015 & 0.019 & 0.118 \\
\hline & $S^{\prime} r_{s}^{\prime}$ & 0.132 & $0.227^{*}$ & -0.014 & 0.014 & 0.052 & 0.132 \\
\hline \multirow[t]{2}{*}{ 13. Working practices (WP) } & $P^{\prime} r_{s}^{\prime}$ & 0.050 & $0.326^{\star *}$ & -0.073 & 0.086 & -0.026 & -0.002 \\
\hline & $S^{\prime} r_{s}^{\prime}$ & 0.074 & $0.316^{\star \star}$ & -0.030 & 0.082 & 0.017 & 0.012 \\
\hline \multirow[t]{2}{*}{ 14. Estimates (WP) } & $P^{\prime} r_{s}^{\prime}$ & 0.120 & 0.179 & -0.129 & 0.027 & $0.219^{*}$ & $0.241^{*}$ \\
\hline & $S^{\prime} r_{s}{ }^{\prime}$ & 0.167 & 0.162 & -0.111 & 0.033 & $0.214^{*}$ & $0.295^{\star *}$ \\
\hline \multirow[t]{2}{*}{ 15. Risk \& uncertainty (WP) } & $P^{\prime} r_{s}^{\prime}$ & 0.135 & $0.245^{\star}$ & -0.049 & 0.034 & 0.193 & 0.118 \\
\hline & $S^{\prime} r_{s}{ }^{\prime}$ & 0.207 & $0.217^{*}$ & 0.018 & 0.003 & 0.190 & 0.111 \\
\hline \multirow[t]{2}{*}{ 9. Feedback (HS) } & $P^{\prime} r_{s}^{\prime}$ & -0.062 & $0.310^{\star *}$ & 0.075 & 0.089 & -0.034 & 0.062 \\
\hline & $S^{\prime} r_{s}^{\prime}$ & -0.065 & $0.311^{* *}$ & 0.111 & 0.106 & 0.034 & 0.060 \\
\hline \multirow[t]{2}{*}{ 3. Identification of needs (SDS) } & $P^{\prime} r_{s}^{\prime}$ & -0.079 & 0.080 & -0.158 & 0.009 & 0.015 & -0.032 \\
\hline & $S^{\prime} r_{s}^{\prime}$ & -0.093 & 0.064 & -0.160 & 0.011 & -0.015 & -0.039 \\
\hline \multirow[t]{2}{*}{ 1. Resources (SDS) } & $P^{\prime} r_{s}^{\prime}$ & -0.190 & 0.104 & -0.108 & 0.172 & 0.068 & -0.027 \\
\hline & $S^{\prime} r_{s}^{\prime}$ & -0.138 & 0.109 & -0.094 & 0.188 & 0.131 & -0.001 \\
\hline \multirow[t]{2}{*}{ LCQ Summary variable (LCQ) } & $P^{\prime} r_{s}^{\prime}$ & 0.074 & $0.288^{\star *}$ & -0.112 & 0.117 & 0.123 & 0.173 \\
\hline & $S^{\prime} r_{s}^{\prime}$ & 0.149 & $0.363^{* * *}$ & -0.016 & 0.115 & 0.133 & $0.250^{*}$ \\
\hline \multirow[t]{2}{*}{ Human Support (HS) } & $P^{\prime} r_{s}^{\prime}$ & 0.103 & 0.147 & -0.104 & 0.101 & 0.141 & 0.170 \\
\hline & $S^{\prime} r_{s}{ }^{\prime}$ & 0.117 & 0.150 & -0.019 & 0.055 & 0.149 & 0.206 \\
\hline \multirow[t]{2}{*}{ Working Practices (WP) } & $P^{\prime} r_{s}^{\prime}$ & 0.190 & $0.279^{\star \star}$ & -0.110 & 0.039 & 0.157 & $0.227^{*}$ \\
\hline & $S^{\prime} r_{s}^{\prime}$ & $0.295^{\star *}$ & $0.299^{* *}$ & -0.037 & 0.006 & 0.136 & $0.261^{*}$ \\
\hline \multirow{2}{*}{$\begin{array}{lll}\text { Staff } & \text { Development } & \text { Systems } \\
\text { (SDS) } & & \end{array}$} & $P^{\prime} r_{s}{ }^{\prime}$ & -0.108 & 0.203 & -0.111 & 0.106 & 0.036 & 0.000 \\
\hline & $S^{\prime} r_{s}{ }^{\prime}$ & -0.074 & $0.222^{*}$ & -0.092 & 0.127 & 0.077 & 0.032 \\
\hline
\end{tabular}

Table 8 Correlations between Learning Climate Questions and Approaches to Learning at work Questionnaire factor scores $(n=84)$

P ' $r$ ' = Pearson's Correlation Coefficients, S 'rs' = Spearman's Correlation Coefficients 
While neither the Human Support factor score nor three out of the eight items linked to Human Support correlated significantly with any ALQ factor score, the LCQ item related to obtaining feedback on one's performance correlated significantly and positively with the Selfmanagement factor score, and the item linked to taking personal responsibility correlated significantly and positively with the Self-confidence factor score (both at the $1 \%$ level)

The findings indicate that the practitioners rated their ability to:

- self-manage their approach to learning more highly when they perceived the overall learning environment and specifically the working practices of the organisation to be supportive, and where they obtained feedback on their performance;

- be self-confident in their approach to learning more highly when they perceived the overall learning environment and specifically the working practices of the organisation to be supportive, and where they were given personal responsibility and received support from their colleagues;

- take risks in their approach to learning more highly when they perceived the working practices (standards) of the organisation to be supportive and where they were given personal responsibility.

The significance of the learner's environment to learning is established within the existing literature. Ogunlana (1989), quoting from Feldman (1986), had suggested that surveying organisations should create a social environment that requires learning to improve learning from experience and, therefore, their estimating performance. These findings establish the relationship between an individual's approach to learning and the learning climate.

\section{Investigation of the Time/Size Interaction}

To investigate further the interaction between time in the profession and size of the organisation on the practitioner's perception of the learning climate of their organisation, the following tests were performed:

\section{Tests for differences}

The items of the LCQ and four summary variables were tested for differences between 4 subgroups based on time in the profession/size of the practice interaction: small size/low experience ( $\mathrm{S} 1: \mathrm{T} 1, \mathrm{n}=22)$, small size/high experience $(\mathrm{S} 1: \mathrm{T} 2, \mathrm{n}=20)$, large size/low experience (S2:T1, $n=20)$ and large size/high experience $(S 2: T 2, n=22)$. The results are presented in Table 2.

Closer examination using Bonferroni's post hoc multiple comparison test revealed that the Human Support factor score and the LCQ items linked to the friendliness of the organisation, personal responsibility, and people sharing information were rated significantly higher by practitioners in small size practices with high experience (S1:T2) than practitioners in large size practices with low experience (S2:T1). Also, the Staff Development Systems factor score and the LCQ items associated with the identification of needs, and the provision of resources were rated significantly higher by practitioners in large size practices with low experience (S2:T1) than practitioners in small size practices with low experience (S1:T1). Additionally, practitioners in large size practices with low experience (S2:T1) rated the item associated with the provision of resources significantly higher than practitioners in small size practices with high experience. Interestingly, there were no significant differences for the Working Practices factor score, any LCQ item associated with Working Practices or the LCQ summary variable.

\section{Partial correlation}

Partial correlation coefficients were calculated between the four LCQ summary variables and the three measures of the length of experience of the practitioners (the number of years as 
an estimator, the number of years of specialism within estimating and the number of years as a corporate member of the RICS) controlling for size of the practice and then again controlling for the size of the organisation. Partial correlation coefficients were also calculated between the four LCQ summary variables and the two measures of the size of the practice (the practitioner's office) and the size of the practitioner's organisation as a whole, controlling for time in the profession.

Time: Human Support was found to correlate significantly and positively with the number of years of specialism as an estimator at the $5 \%$ level, when controlling for size of practice. Further, no other significant relationships were established when controlling for size of the organisation.

Size: Staff Development Systems correlates significantly and positively with the size of the organisation at the $1 \%$ level, when controlling for time in the profession.

\section{Regression analysis}

To investigate the time/size interaction further, multiple regression analysis was carried out with the Human Support, Working Practices, Staff Development Systems, and LCQ summary variables as dependent variables. The independent variables were position, time, log-sizeP (size of practice), log-sizeT (size of organisation), size-timeP interaction, sizetimeT interaction, 6 learning styles, and 6 approaches to learning factor scores.

For the Human Support summary variable both forward and backward regression analysis confirmed the significance of position as the sole significant predictor.

For the Working Practices summary variable both forward and backward regression analysis found position and self-confidence to be significant predictors, while backward regression analysis also found self-management to be a significant predictor.

For the Staff Development Systems summary variable both forward and backward regression analysis confirmed the significance of log-size T, self-management and position as predictor variables.

For the LCQ summary variable regression analysis both forward and backward regression analysis confirms the significance of position, self-management and log-sizeT as important predictors.

\section{Summary}

\section{Human Support}

The learning environment within quantity surveying organisations is perceived to be supportive in terms of Human Support. This was particularly the case for senior managers who rated the provision of Human Support significantly higher than the employee respondents. Further, the significance of position was confirmed by the results of the regression analysis.

The practitioners' perception of Human Support increases significantly with measures of time in the profession, but also decreases significantly as the size of the organisation increases. The relationship between Human Support and time in the profession was confirmed by the results of partial correlation when controlling for size. Further, practitioners in small size practices with high experience rated the provision of Human Support significantly higher than practitioners in large size practices with low experience.

\section{Working Practices}

The partners/directors perceived the learning environment within quantity surveying organisations to be more supportive in terms of Working Practices than the employee 
respondents. The significance of position was confirmed by the results of the regression analysis.

The practitioners' perception of Working Practices was found to increase significantly with measures of time in the profession; however, this relationship was not confirmed by the results of partial correlation when controlling for size.

A positive relationship was established between Working Practices and the learning style Concrete Experience, while individual LCQ items related to Working Practices were linked to Abstract Conceptualization and Active Experimentation. The significance of these relationships, however, was not confirmed by the results of the regression analysis. Also, Working Practices are linked positively with the approaches to learning Self-management, Risk-taking and Self-confidence. The significance of Self-management and Self-confidence was confirmed by the results of the regression analysis.

\section{Staff Development Systems}

The learning environment was perceived to be less supportive in terms of Staff Development Systems, particularly relating to the identification of needs and the provision of learning resources, both overall and by the partner/director and employee subgroups.

The practitioners' perception of Staff Development Systems increases significantly as the size of the organisation increases. This relationship was confirmed by the results of partial correlation when controlling for time in the profession and by the results of the regression analysis. Further, practitioners in large size practices with low experience rated the provision of Staff Development Systems significantly higher than practitioners in small size practices with low experience. Additionally, practitioners in large size practices with low experience also rated the item related to the provision of resources significantly higher than practitioners in small size practices with high experience.

\section{The Overall Learning Environment (summary variable)}

The partners/directors perceived the overall learning environment within quantity surveying organisations (as measured by the LCQ Summary variable) to be more supportive than the employee respondents. The significance of position was confirmed by the regression results.

A positive relationship was established between the overall learning environment and the learning style Concrete Experience. Also, the LCQ summary variable is linked positively with Self-management and Self-confidence: the higher a practitioner rates an organisation in terms of its overall learning climate the higher they rate their ability to self-manage and be more self-confident in their approach to learning. The significance of Self-management was confirmed by the results of the regression analysis.

\section{Conclusions}

The following conclusions have been drawn from the investigation.

- The learning environment within quantity surveying organisations is perceived to be supportive in terms of human support but less supportive in terms of staff development systems.

- As an individual rises in the hierarchy of an organisation, their perception of its ability to provide an appropriate learning environment increases. Senior managers (partners/directors) considered the overall learning environment within quantity surveying organisations, the provision of human support and working practices to be more supportive than the employee respondents. Further, the practitioners' perception of human support and working practices increases significantly with measures of time in the profession. 
- The practitioners' perception of their organisation's ability to provide appropriate staff development systems increases, while their perception of its ability to provide human support decreases, as the size of the organisation increases.

- The provision of human support was rated significantly higher by practitioners in small size practices with high experience than practitioners in large size practices with low experience; while, practitioners in large size practices with low experience rated the provision of staff development systems significantly higher than practitioners in small size practices with low experience. Additionally, practitioners in large size practices with low experience also rated the item related to the provision of resources significantly higher than practitioners in small size practices with high experience.

- A positive relationship was established between the learning style Concrete Experience the overall learning environment and working practices, while individual LCQ items related to working practices were linked to Abstract Conceptualization and Active Experimentation. This suggests that the more support for 'Freedom to Learn' an individual receives from their organisation the more likely they will be to participate in experiential learning. This is especially true for the active dimensions (Concrete Experience and Active Experimentation), which are apparent to their peers and employers.

- The higher a practitioner rates an organisation's overall learning climate and specifically its working practices the higher they rate their ability to self-manage and be more self-confident in their approach to learning. Additionally, the higher a practitioner rates an organisation's working practices the higher they rate their ability to be risk-taking in their approach to learning.

Despite the recommendations of Flanagan and Norman (1983), Morrison (1984) and Ogunlana (1989) many quantity surveying organisations appear to have weak formal feedback systems. This is likely to be particularly important insofar as early stage building price forecasting is concerned, as current knowledge of market conditions, local contractors' workloads, etc., is likely to be a major determinant of how well the surveyors can perform this task. Practitioners gave a low rating to the provision of constructive feedback by the organisation on their performance. Surveying organisations should consider introducing effective feedback mechanisms that require both the individual to critically reflect on their own performance and the organisation to provide effective constructive feedback on an individual's performance.

While surveying organisations are perceived to be supportive in terms of human support, especially by senior managers in small size organisations, they are perceived to be less supportive in terms of staff development systems. Further, the significant differences between the perceptions of the partner/directors and their employees could suggest that they are not in tune with the organisations learning climate. Those practitioners who are in a position to most influence the organisational culture, therefore, perceived the organisation to be significantly better in providing an appropriate environment than their employees. Surveying organisations are dependent, to a large extent, on the skills and abilities of individual and groups of surveying staff. Therefore, as Mumford (1991) has argued, it is only by the effective deployment and use of learning opportunities that organisations will enable themselves to change and continue to function effectively in a turbulent environment. The implication of this is that surveying organisations may need to more accurately assess their ability to provide an effective learning environment and to address any deficiencies, especially in the provision of staff development systems, to maintain performance and thereby possibly increase their quality of service and competitive advantage.

As with most empirical studies of this nature, the results provide more questions than answers. Why are larger organisations perceived to have better Staff Development Systems

Lowe, D and Skitmore, M (2011) 'The learning climate of chartered quantity surveying practices', Australasian Journal of Construction Economics and Building, 11 (4) 1-20 
but worse Human Support than smaller organisations? Is this a faulty or accurate impression of the staff involved? If the impressions are correct, then is this situation optimal for these organisations or not? If it is optimal, what are the reasons? If not, then what is preventing organisations from doing this better? Likewise, why do the more senior and more experienced practitioners perceive their learning climate to be better than the other practitioners? Are the perceptions of one or both of the groups faulty and, if so, why are they faulty and to what extent does that matter? And again, if they are correct, to what extent is the situation optimal or suboptimal and why? These issues seem to be worthy of more study.

Also, at a more general level, there is the question of whether these findings are applicable to North West England quantity surveying practices only? We don't yet know if the same situation exists for other building professions and/or in other parts of UK or the world in general. In addition, much of the results of this survey resonate loudly or those of us who now work in the educational/research industry - suggesting an even broader study could be quite revealing.

Finally, it should be mentioned that a recurring theme of surveys in the project and construction management field concerns the significant differences in perceptions between the younger and more experienced practitioners involved - suggesting the existence of a "generation-gap" of consequence. Of course, it is easy for those more established personnel to decry the perceptions and opinions of the new order as being ill-informed and impractical, but there is a lingering suspicion that change may be needed and necessary after all. Times have changed considerable since the "old-days". No longer do practitioners mature gradually over a lengthy period of learning almost entirely on-the-job. Instead, they emerge full-qualified from the tertiary education system with only a relatively superficial awareness of the real practical knowledge and skills to operate in day to day practice. On the other hand, these newly qualified practitioners do have the potential to see overviews that are less obvious to their more senior colleagues and therefore, as well as representing the future of the industry, surely need to be listened to more closely.

\section{References}

Barron, C. (2004) 'Fair play: creating a better learning climate for social work students in social care settings', Social Work Education, 23 (1), 25-37

Binsted, D. (1980) 'Design for learning in management training and development: A view', Journal of European Industrial Training, 4 (8), 1-32

Chou, S-W., Lui, C-H. (2005) 'Learning effectiveness in a web-based virtual learning environment: a learner control perspective web-based virtual learning environment', Journal of Computer Assisted Learning , 21 (1), 65-76

Chou, T-C., Chang, P-L., Tsai, C-T., Cheng, Y-P. (2005) 'Internal learning climate, knowledge management process and perceived knowledge management satisfaction', Journal of Information Science, 31 (4) 283-296

Chun-Heung, L., French, P. (1997) 'Education in the practicum: a study of the ward learning climate in Hong Kong', Journal of Advanced Nursing, 26 (3), 455-462

Eraut, M. (1994) Developin g professional knowledge and competence, The Falmer Press, London

Feldman, J. (1986) 'On the difficulty of learning from experience', in The thinking Organisation, Dynamics of Organisational Social Cognition, Sims, Gioia and Associates (eds) Jossey Bass, San Francisco

Flanagan, R., Norman, G. (1983) 'The accuracy and monitoring of quantity surveyors' price forecasting for building work', Construction Management and Economics, 1 (2), 157-180 
Freedman, M.B. (1967) The student and campus climates of learning, US Department of Health, Education and Welfare, Washington

Geiger, M.A., Boyle, E.J. Pinto, J.K. (1993) 'An examination of ipsative and normative versions of Kolb's revised Learning Style Inventory', Educational and Psychological Measurement, 53, 717-26

Gibbs, G. (1988) Learning by doing - A guide to teaching and learning methods, F.E.U.

Gish, G. (1980) Adult development and adaptation: An empirical test of the experiential learning theory and adaptive flexibility, Unpublished doctoral dissertation, Case Western Reserve University

Harri-Augustein, S., Thomas, L. (1991) Learning conversations: the self-organised learning way to personal and organisational growth. Routledge, London

Honey, P., Mumford, A. (1989) The manual of learning opportunities, P. Honey and A. Mumford, Maidenhead

Jarvis, P. (1987) Adult learning in the social context, Croom Helm, London

Kolb, D.A. (1976) The learning style inventory: technical manual, McBer \& Co., Boston, Mass

Kolb, D.A. (1984) Experiential learning: experience as the source of learning and development, Prentice - Hall, New Jersey

Kolb, D.A. (1985) Learning style inventory: technical manual (Revised edition), McBer \& Co., Boston, Mass

Kolb, D.A., Rubin, K.M., McIntyre, J.M. (1979) Organisational psychology: an experimental approach, 3rd Edition, Prentice - Hall, New Jersey

Lewis, R., Margerison, C. (1979) 'Working and learning - identifying your preferred ways of doing things', Personnel Review, 8 (2), 25-29

Lovell, R.B. (1980) Adult learning, Croom Helm, London

Lowe, D.J., Skitmore, R.M. (1994) 'Experiential learning in cost estimating', Construction Management and Economics 12 (5) 423-31

Lowe, D.J., Skitmore, R.M. (2001) 'Human effects in construction contract price forecasting: experience and experiential learning styles', Journal of Construction Engineering and Management, 127 (6), 485-493

Lowe, D.J., Skitmore, R.M. (2007) 'The learning climate of an organisation and practitioner competence', Journal of Financial Management of Property and Construction 11 (3) 151-64

Manring, S. (1979) Career patterns of technically trained professionals: A person/environment interaction model, Unpublished doctoral dissertation, Case Western Reserve University

Marsick, V.J., Watkins, K.E (1990) Informal and incidental learning in the workplace, Routledge, London

Mikkelsen, A. (1998) 'Job stress and organizational learning climate', International Journal of Stress Management, 5 (4),197-209

Miller, C.W. (1978) The effects of work experience and undergraduate education on the learning style and career development of technical professionals, Unpublished doctoral dissertation, Case Western Reserve University

Morrison, N. (1984) 'The accuracy of quantity surveyors cost estimating', Construction Management and Economics, 2 (1), 57-75

Morrison, R.F. and Brantner, T.M. (1992) 'What enhances or inhibits learning a new job? A basic career issue', Journal of Applied Psychology, 77 (6), 926-940 
Mumford, A. (1980) Making experience pay - management success through effective learning, McGraw - Hill, London

Mumford, A. (1981) 'What did you learn today?', Personnel Management, August, 35-39

Mumford, A. (1986) 'Learning to learn for managers', Journal of European Industrial Training, 10 (2), 1-28

Mumford, A. (1987) 'Learning styles and learning', Personnel Review, 6 (5), 20-23

Mumford, A. (1990) 'The individual and learning opportunities', Industrial and Commercial Training, 22 (1), 17-22

Mumford, A. (1991) 'Individual and organisational learning: balance in the pursuit of change', Studies in Continuing Education, 13 (2), 115 - 125

Myrick, F., Yonge, O.J. (2001) 'Creating a climate for critical thinking in the preceptorship experience', Nurse Education Today, 21 (6), 461-467

Ogunlana, S.O. (1989) Accuracy in design cost estimating, PhD thesis, Loughborough University of Technology

Ogunlana, S.O. (1991) 'Learning from experience in design cost estimating', Construction Management and Economics, 9 (3), 133-150

Ortenblad, A. (2002) 'A typology of the idea of learning organization', Management Learning, $33(2), 213$

Pedler, M., Burgoyne, J., Boydell, T. (1991) The learning company: A strategy for sustainable development, McGraw-Hill Book Company, London

Ramsden, P. (1988) Context and strategy: situational influences on learning, in learning strategies and learning styles, R.R. Schmeck (ed), Plenum Press, New York

Richardson, J.T.E. (1990) 'Reliability and replicability of the approaches to studying questionnaire', Studies in Higher Education, 15 (2), 155-168

Rogers, A. (1986) Teaching adults, Open University Press, Buckingham

Rosenthal, R., Rosnow, R. L. (1991) Essentials of behavioural research: Methods and data analysis (2nd ed.). New York: McGraw-Hill

Ruble, T.L., Stout, D.E. (1991) 'Reliability, classification stability, and response-set bias of alternate forms of the Learning-Style Inventory (LSI-1985)', Educational and Psychological Measurement, 51 481-89

Schultz, K.W., Kirby, J., Delva, D., Godwin, M., Verma, S., Birtwhistle, R., Knapper, C., Seguin, R. (2004) 'Medical students' and residents' preferred site characteristics and preceptor behaviours for learning in the ambulatory setting: a cross-sectional survey', BMC Medical Education, 4 (1) 4-12

Sims, R.R. (1983) 'Kolb's experiential learning theory: A framework for assessing person-job interaction', Academy of Management Review, 8, 501-508

Smith, R.M. (1982) Learning how to learn: applied theory for adults, The Open University Press, Milton Keynes

Snell, R. (1992) 'Experiential learning at work: why can't it be painless?', Personnel Review, 21 (4), 12-26

Thompson, A (2004) 'Chartered Quantity Surveyors - masters of all they survey', Guardian Newspaper, 17 December

Vandenput, M.A.E. (1973) 'The transfer of training: some organisational variables', Journal of European Training, 2 (3), 251-262 